\title{
Principal's Interpersonal Conflict Management: A Literature Review
}

\author{
Umigiarini Pangestu, Sowiyah, Mutiara Nur Ahlaini, Felia Santika \\ Department Teacher Training and Education, Lampung University, Indonesia
}

\begin{abstract}
The importance of interpersonal conflict management for principals makes researchers interested in making literature reviews. There are many articles that discuss interpersonal conflict management for principals. This article is a literature review that aims to find out the interpersonal conflict management of the principal and the principal's strategy in managing conflict, so it will give a positive impact on the environment of the school organization. Based on the results of literature reviews from many studies in various countries in the world, it is known that conflict has a positive effect when managed together effectively and can be very useful for the effectiveness of individuals and groups and will affect the sustainability of school organizations. So, we are interested to follow up research related to Interpersonal Conflict Management for the Principal.
\end{abstract}

Keywords: Conflict Management, Interpersonal Principal, Interpersonal conflict management strategies

\section{INTRODUCTION}

$\mathrm{M}$ ust be possessed by the principal is management. Managerial competence (management) requires the principal to be able to plan, to develop, to overcome, and to manage all available resources in school optimally, both human and non-human resources. Besides, managerial competence is intended to produce leaders who are able to create a conducive and innovative school culture (Muslim, 2014). The success of an organization, such as a school, depends on the quality of the leader in making a decision (Hariri, Monypenny, \& Prideaux, 2014). The different in characteristics, background, work intensity, interests, and goals of each member of the organization allows conflict to grow (Beenen, Pichler, \& Davoudpour, 2018). Three main things in dealing with problems in an organization or institution are perception, emotions and communication (Wulandari, 2019). The results of conflict can have positive or negative, destructive or constructive effects. Some positive results can create new ideas, release tension, re-evaluate and clarify goals, and strengthen collaboration between team members in the future.

Conflict resolution in an educational institution becomes the task of a leader, in this case the Principal, who leads the staff, teachers, and all students (Lalegani, Isfahani, Shahin, \& Safari, 2019). A school principal must be able to manage conflict. Conflict management is one of the efforts to deal with problems, both conflicts within his self and conflicts with others (Sridasweni, Yusuf, \& Sabandi, 2017). Interpersonal conflict is a very important dynamic in organizational behavior. Because this conflict will involve several members of the organization that can influence the process of achieving organizational goals (Siswidiyanto \& Puspasari, 2018).

Wahjosumidjo stated that the principal is a functional teacher who is given the task to lead a school where teaching and learning is held or where interaction occurs between the teacher and student (Djafri, 2020). Leadership competence in interpersonal conflict promotes structured thinking and is very important for solving management problems (Englefield, Black, Copsey, \& Knight, 2019). Some researchers argue that diversity and conflict facilitate team effectiveness by promoting understanding of complex problems and developing good quality solutions. A conflict can encourage group members to improve their thinking, look for more effective ideas, be open minded and consider opposing perspectives, combine diverse ideas into creative and highquality decisions that are committed to being implemented in order to achieve a school organization's goals. There are several issues related to interpersonal conflict management for principals. To find the answer of these issues, a literature review will be conducted on "Interpersonal Conflict Management for Principals".

\section{METHODOLOGY}

The review of this library focuses on the Principal's Interpersonal Conflict Management.

Search and Review Methods

The review process starts from the search engine, Google Scholar, to search for articles with keywords: "Interpersonal Conflict Management". The search ranged from articles to the 2013-2020 publication year, identified 150 studies and articles related to the topic. Criteria for articles that can be used in this study are:

a. Qualitative and quantitative results of relationships about interpersonal management of principals.

b. Research from various countries in the world

c. The articles were written in english

d. Dissertations and theses are excluded

The steps in this Literature Review are:

Step 1: Formulate the Problem 
- Choose a topic that fits the issue and interest

- The problem must be written completely

Step 2: Find Literature

- Find literature that is relevant to the research Get an overview of the research topic

- Research sources are very helpful if supported by knowledge of the topic.

- The articles provide an overview/summary of previous research.

\section{Step 3: Data Evaluation}

- Focus on articles' findings/contributions related to the topics discussed

- Find the right data source as needed to support research

- Data can be in the form of qualitative data, quantitative data or a combination of both

Step 4: Analysis and Interpretation

Discuss and find and summarize the literature

Table 1. Interpersonal Conflict Management in School

\begin{tabular}{|c|c|c|c|c|c|}
\hline $\begin{array}{c}\text { Author and } \\
\text { Publication Year }\end{array}$ & Title & Country & Methods & Sample & Findings \\
\hline $\begin{array}{l}\text { Moch. Khafidz } \\
\text { Fuad Raya (2016) }\end{array}$ & $\begin{array}{l}\text { Resolusi Konflik Dalam } \\
\text { Institusi Pendidikan Islam } \\
\text { (Conflict Resolution in } \\
\text { Islamic Education Institution) }\end{array}$ & Indonesia & Descriptive & ------------- & $\begin{array}{l}\text { Based on this research, conflicts in school can } \\
\text { have positive and negative impacts, and can } \\
\text { encourage innovation, creativity, and adaptation. } \\
\text { Conflicts that are well managed can be used as a } \\
\text { means of change. However, if the conflict is not } \\
\text { managed properly, it will adversely affect the } \\
\text { school organization. }\end{array}$ \\
\hline $\begin{array}{l}\text { Federica Vallone, } \\
\text { Elena } \\
\text { Dell'Aquil,Maria } \\
\text { Clelia Zurlo, } \\
\text { Davide Marocco } \\
\text { (2019) }\end{array}$ & $\begin{array}{l}\text { Design Methods for Training } \\
\text { Teachers in Conflict } \\
\text { Management Within Multi- } \\
\text { Ethnic and Multicultural } \\
\text { Classes: A Proposed } \\
\text { Psychological Framework }\end{array}$ & Italy & Qualitative & ------- & $\begin{array}{l}\text { This study provides information that management } \\
\text { styles for interpersonal conflict refer to two basic } \\
\text { dimensions: self-care (the level at which } \\
\text { individuals aim to satisfy their own beliefs in the } \\
\text { conflict management process) and care for others } \\
\text { (the level at which individuals try to resolve } \\
\text { conflicts by empathy). }\end{array}$ \\
\hline $\begin{array}{l}\text { Rommel Pilapil } \\
\text { Sergio (2015) }\end{array}$ & $\begin{array}{c}\text { Emotional Intelligence, Work } \\
\text { or Family Conflict, and Work } \\
\text { Value Between Customer } \\
\text { Representatives: Basis for } \\
\text { Organizational Support }\end{array}$ & Dubai & Qualitative & $437 \mathrm{CSR}$ & $\begin{array}{l}\text { The findings of this study stated that there is a } \\
\text { significant relationship between emotional } \\
\text { intelligence and work or family conflict. In } \\
\text { addition, it was also found that there is a } \\
\text { significant relationship between emotional } \\
\text { intelligence with work values in determining the } \\
\text { future of the organization. }\end{array}$ \\
\hline $\begin{array}{l}\text { Gerard Beenen, } \\
\text { Shaun Pichler, dan } \\
\text { Shahin } \\
\text { Davoudpour } \\
\text { (2018) } \\
\end{array}$ & $\begin{array}{l}\text { Interpersonal Skills in MBA } \\
\text { Admissions: How Are They } \\
\text { Conceptualized }\end{array}$ & California & Quantitative & 1.365 schools & $\begin{array}{l}\text { Based on this study, differences in the } \\
\text { characteristics, background, work intensity, } \\
\text { interests, and goals of each member of the } \\
\text { organization can create conflicts within an } \\
\text { organization. }\end{array}$ \\
\hline $\begin{array}{l}\text { Dede Mustomi, } \\
\text { Siswidiyant, } \\
\text { Aprilia Puspasari } \\
\quad(2020)\end{array}$ & $\begin{array}{l}\text { Pengaruh Komunikasi Dan } \\
\text { Kepemimpinan Dalam } \\
\text { Penyelesaian Konflik }\end{array}$ & Indonesia & Correlation & 53 people & $\begin{array}{l}\text { The findings of this study revealed that, conflicts } \\
\text { within organizations can be reduced through } \\
\text { adequate work, detailed specifications on } \\
\text { relationships between positions, and } \\
\text { comprehensive training for "the use of resolution } \\
\text { and stimulation techniques to achieve the desired } \\
\text { degree of conflict". }\end{array}$ \\
\hline $\begin{array}{c}\text { Englefield, Black, } \\
\text { Copsey,\& Knight, } \\
\text { (2019) }\end{array}$ & $\begin{array}{c}\text { Interpersonal competencies } \\
\text { define effective conservation } \\
\text { leadership }\end{array}$ & London & Qualitative & $\begin{array}{l}5 \text { professional } \\
\text { organizations }\end{array}$ & $\begin{array}{l}\text { The ability to build trust between individuals is } \\
\text { considered as the most important leadership } \\
\text { competency. These beliefs include; Strong } \\
\text { interpersonal skills, promote a strong team } \\
\text { culture, and lead the team to higher performance. }\end{array}$ \\
\hline $\begin{array}{l}\text { Solomon Taayina } \\
\text { Ane (2019) }\end{array}$ & $\begin{array}{c}\text { Mechanisms For Preventing, } \\
\text { Managing And Resolving } \\
\text { Inter-Religious Conflicts In } \\
\text { Some Selected Senior High } \\
\text { Schools In The Upper West } \\
\text { Region } \\
\end{array}$ & Ghana & Qualitative & 230 Respondents & $\begin{array}{l}\text { Conflict management has } 5 \text { models: } \\
\text { accommodate, avoid, collaborate, compete and } \\
\text { compromise. The most widely used are two main } \\
\text { dimensions: assertive and cooperative. }\end{array}$ \\
\hline $\begin{array}{l}\text { Owan, Valentine } \\
\text { Joseph (2018) }\end{array}$ & $\begin{array}{c}\text { Conflict Management } \\
\text { Strategies And Secondary } \\
\text { School Teachers' Job } \\
\text { Effectiveness In Obubra } \\
\text { Local Government Area Of } \\
\text { Cross River State, Nigeria. } \\
\end{array}$ & $\begin{array}{l}\text { Cross River } \\
\text { State }\end{array}$ & $\begin{array}{l}\text { Correlation } \\
\text { with factorial } \\
\quad \text { design }\end{array}$ & 222 Teachers & $\begin{array}{l}\text { The study shows that there are four conflict } \\
\text { management strategies (arbitration, dialogue, } \\
\text { effective communication and smoothing) that } \\
\text { have a joint and significant influence on teacher } \\
\text { performance in secondary school. }\end{array}$ \\
\hline $\begin{array}{l}\text { Yemeng Lu- } \\
\text { Myers, and }\end{array}$ & $\begin{array}{l}\text { Incorporating Interpersonal } \\
\text { Skills into Otolaryngology }\end{array}$ & United States & Qualitative & ------ & $\begin{array}{l}\text { The findings of this study showed that skills and } \\
\text { strategies for managing personal conflicts and }\end{array}$ \\
\hline
\end{tabular}




\begin{tabular}{|c|c|c|c|c|c|}
\hline $\begin{array}{l}\text { Christopher G. } \\
\text { Myers (2018) }\end{array}$ & $\begin{array}{l}\text { Resident Selection and } \\
\text { Training }\end{array}$ & & & & $\begin{array}{l}\text { working in teams are very necessary. Selecting } \\
\text { skills in important interpersonal leadership } \\
\text { represents a dual assessment and development } \\
\text { process that contributes to knowledge, } \\
\text { excellence, skills and abilities }\end{array}$ \\
\hline $\begin{array}{l}\text { Andrea E. Zuelke } \\
\text { (2020) }\end{array}$ & $\begin{array}{l}\text { Are social conflicts at work } \\
\text { associated with depressive } \\
\text { symptomatology? Results } \\
\text { from the population-based } \\
\text { LIFE-Adult-Study }\end{array}$ & Europe & Qualitative & ------ & $\begin{array}{l}\text { This research reveals that, related to the } \\
\text { emergence of a conflict, it is necessary to do a } \\
\text { conflict mapping. Conflict mapping is the first } \\
\text { step that must be done in solving a problem, both } \\
\text { in individuals and groups so that we can manage } \\
\text { conflicts properly }\end{array}$ \\
\hline $\begin{array}{l}\text { James B. Abugre } \\
\text { (2020) }\end{array}$ & $\begin{array}{c}\text { The Moderating Role of } \\
\text { Affective Interpersonal } \\
\text { Conflict on Managerial } \\
\text { Decision-making and } \\
\text { Organizational Performance } \\
\text { in Private Sector } \\
\text { Organizations: A Study of } \\
\text { Ghana } \\
\end{array}$ & Ghana & Quantitative & $\begin{array}{l}197 \text { managers in } \\
\text { Ghina }\end{array}$ & $\begin{array}{l}\text { The findings of this study reveal the fact that } \\
\text { interpersonal conflict supports the relationship } \\
\text { between managerial decisions in organizational } \\
\text { performance. }\end{array}$ \\
\hline $\begin{array}{l}\text { Elisavet Chandolia } \\
\text { and Sophia Anasta } \\
\text { siou (2020) }\end{array}$ & $\begin{array}{c}\text { Leadership and Conflict Man } \\
\text { agement Style are Associated } \\
\text { with the Effectiveness of Sch } \\
\text { ool Conflict Management in t } \\
\text { he Region of Epirus, NW Gre } \\
\text { ece }\end{array}$ & Greece & Quantitative & 128 Teachers & $\begin{array}{l}\text { The findings of this study indicate that the style } \\
\text { of leadership and conflict management is related } \\
\text { to the effectiveness of conflict management } \\
\text { demonstrated by the School Principal. In-service } \\
\text { or pre-service training of school principals in } \\
\text { human resource management skills, including } \\
\text { leadership and conflict management, can help } \\
\text { improve the efficiency of schools. Effective } \\
\text { conflict management can create conditions that } \\
\text { will improve school climate, job satisfaction and } \\
\text { teacher commitment and school performance. }\end{array}$ \\
\hline $\begin{array}{l}\text { Lynne Kerrigan } \\
\text { (2019) }\end{array}$ & $\begin{array}{l}\text { Strategies for managing } \\
\text { conflict within a team }\end{array}$ & $\begin{array}{l}\text { United } \\
\text { Kingdom }\end{array}$ & Qualitative & ---------- & $\begin{array}{l}\text { An unresolved conflict will cause an increased } \\
\text { level of stress and eventually arise feelings of } \\
\text { anger and hatred, which can seriously damage the } \\
\text { team and can eventually be threatening. Before } \\
\text { dealing with individuals, leaders can think of } \\
\text { strategies in overcoming problems, so that } \\
\text { problem solving will be more controlled, rational } \\
\text { and remain on target }\end{array}$ \\
\hline $\begin{array}{l}\text { Mehmet } \\
\text { Üstüner,Ali Kiş } \\
\text { (2014) }\end{array}$ & $\begin{array}{l}\text { The Relationship between } \\
\text { Communication Competence } \\
\text { and Organizational Conflict: } \\
\text { A Study on Heads of } \\
\text { Educational Supervisors }\end{array}$ & Turkey & Correlation & $\begin{array}{l}\text { 446 Educational } \\
\text { Supervisors }\end{array}$ & $\begin{array}{l}\text { Based on this study, there is a significant } \\
\text { correlation between school principals conflict } \\
\text { management strategies based on gender and } \\
\text { school culture, emotional intelligence and } \\
\text { conflict management styles, self-confidence and } \\
\text { teacher conflict. Differences between members of } \\
\text { the organization have led to increased conflict } \\
\text { between members who frequently interact with } \\
\text { one another. Poor communication underlies } \\
\text { interpersonal conflict. The level of interpersonal } \\
\text { communication significantly determines the } \\
\text { organization's performance and information } \\
\text { transmission. }\end{array}$ \\
\hline $\begin{array}{l}\text { Hasan Hariri, } \\
\text { Richard } \\
\text { Monypenny, } \\
\text { Murray Prideaux } \\
\text { (2014) }\end{array}$ & $\begin{array}{c}\text { Leadership styles and } \\
\text { decision-making styles in an } \\
\text { Indonesian school context }\end{array}$ & Indonesia & Survey & 475 Teachers & $\begin{array}{l}\text { This research proves that there is a significant } \\
\text { correlation between leadership style and } \\
\text { decision-making style. Each leader has a different } \\
\text { style of decision making for each problem in the } \\
\text { educational organization. }\end{array}$ \\
\hline $\begin{array}{l}\text { Mahbub Parvez, } \\
\text { Mohammad Anisur } \\
\text { Rahman (2020) }\end{array}$ & $\begin{array}{l}\text { Interpersonal Conflict } \\
\text { Management Strategies in } \\
\text { Private Universities of } \\
\text { Bangladesh }\end{array}$ & $\begin{array}{c}\text { Dhaka } \\
\text { (Bangladesh) }\end{array}$ & Quantitative & $\begin{array}{l}29 \text { Officials in } \\
\text { Bangladesh }\end{array}$ & $\begin{array}{l}\text { Based on this research, to gain the trust from the } \\
\text { employees, and to deal with dynamic situations } \\
\text { in dealing with conflict situations, the leaders use } \\
\text { a collaborative approach and a contingency } \\
\text { leadership approach to managing conflict in the } \\
\text { organization }\end{array}$ \\
\hline $\begin{array}{l}\text { Rosmala Dewi } \\
\text { (2013 }\end{array}$ & $\begin{array}{c}\text { Kinerja Kepala Sekolah: } \\
\text { Pengaruh Kepemimpinan } \\
\text { Transformasional, Konflik } \\
\text { Dan Efikasi Diri } \\
\text { (Principal's Performance: Its } \\
\text { Effect on Transformational } \\
\text { Leadership, Conflict and Self- } \\
\text { Efficacy) }\end{array}$ & Indonesia & Explanatory & 200 People & $\begin{array}{l}\text { The principal must have many ideas in solving } \\
\text { problems with conflict management such as; } \\
\text { motivate, inform, inspire, technical } \\
\text { competencies, communicate effectively, and } \\
\text { convey a vision to staff and teachers in order to } \\
\text { achieve organizational goals effectively and } \\
\text { efficiently. }\end{array}$ \\
\hline
\end{tabular}




\begin{tabular}{|c|c|c|c|c|c|}
\hline $\begin{array}{l}\text { Ahmad Muslim } \\
\text { (2014) }\end{array}$ & $\begin{array}{l}\text { Manajemen Konflik } \\
\text { Interpersonal } \\
\text { (Interpersonal Conflict } \\
\text { Management) }\end{array}$ & Indonesia & Qualitative & -------- & $\begin{array}{l}\text { This study states that the causes of interpersonal } \\
\text { conflict are grouped into eight factors: } \\
\text { personality, knowledge, communication, human } \\
\text { relations, discipline, effectiveness of learning, } \\
\text { welfare, and availability of facilities and } \\
\text { infrastructure. Interpersonal conflict approach is } \\
\text { a preventive approach (conflict prevention) and a } \\
\text { curative approach (conflict resolution). }\end{array}$ \\
\hline $\begin{array}{l}\text { Christopher J. } \\
\text { Hopwood, Alana } \\
\text { L. Harrison (2018) }\end{array}$ & $\begin{array}{l}\text { Properties of the Continuous } \\
\text { Assessment of Interpersonal, } \\
\text { Level of Familiarity, and } \\
\text { Interpersonal Conflict }\end{array}$ & United States & Qualitative & 6 Samples & $\begin{array}{l}\text { Based on this research, an interpersonal conflict } \\
\text { approach can be done by letting group members } \\
\text { express their feelings, so, a warm working } \\
\text { atmosphere can be created. Besides, there is a } \\
\text { strong motivation to build, work together, and } \\
\text { seem approachable. }\end{array}$ \\
\hline $\begin{array}{l}\text { Jemal Adem } \\
\text { (2019) }\end{array}$ & $\begin{array}{l}\text { The Practices and Challenges } \\
\text { of Conflict Management in } \\
\text { Government Secondary } \\
\text { Schools in Arada Sub-city in } \\
\text { Addis Ababa }\end{array}$ & $\begin{array}{c}\text { Addis Ababa, } \\
\text { Ethiopia }\end{array}$ & Mix methods & 60 Samples & $\begin{array}{l}\text { The results of interpersonal conflict can be either } \\
\text { positive or negative. Positive results increase } \\
\text { engagement, initiate growth, and strengthen } \\
\text { relationships and increase productivity. } \\
\text { Conversely, negative conflict can destroy morale, } \\
\text { polarize individuals and groups, produce } \\
\text { irresponsible behavior, create suspicion and } \\
\text { distrust, and reduce productivity. }\end{array}$ \\
\hline $\begin{array}{l}\text { Hisny Fajrussalam, } \\
\text { Badrudin } \\
\text { Badrudin, Moh. } \\
\text { Sulhan (2018) }\end{array}$ & $\begin{array}{l}\text { The Influence of Principal's } \\
\text { Communication and Conflict } \\
\text { Management towards the } \\
\text { Work Discipline of Teachers } \\
\text { at SMA PGRI Tanjungsiang } \\
\text { Subang }\end{array}$ & Indonesia & Survey & 15 Teachers & $\begin{array}{l}\text { The results of this study state that school } \\
\text { principal conflict management has a positive } \\
\text { influence on the discipline of teacher } \\
\text { performance. Thus, conflict management plays } \\
\text { an important role in improving the discipline of } \\
\text { teacher performance and conflict management is } \\
\text { one of the important characteristics that must be } \\
\text { possessed by the principal. Conflict will not } \\
\text { happen if the relationships in the organization are } \\
\text { harmonious. }\end{array}$ \\
\hline $\begin{array}{l}\text { Abdul Razzaque } \\
\text { Bhayo, } \\
\text { Prof. Dr. } \\
\text { Naimatullah Shah, } \\
\text { Ayaz Ahmed } \\
\text { Chachar (2017) }\end{array}$ & $\begin{array}{l}\text { The Impact of Interpersonal } \\
\text { Conflict and Job Stress on } \\
\text { Employees Turnover } \\
\text { Intention }\end{array}$ & Pakistan & Survey & $\begin{array}{c}400 \\
\text { Questionnaire }\end{array}$ & $\begin{array}{l}\text { Based on this research, conflict management that } \\
\text { is not managed properly will cause employees to } \\
\text { leave work, to leave the organization, reduce } \\
\text { organizational performance and also reduce the } \\
\text { productivity and profitability of the organization. }\end{array}$ \\
\hline $\begin{array}{c}\text { Pridianti , } \\
\text { Kartika Pricylia } \\
\text { Wulandari (2019) }\end{array}$ & $\begin{array}{l}\text { Interpersonal Communication } \\
\text { Approach to School Head of } \\
\text { Teacher Development }\end{array}$ & Indonesia & Qualitative & ---------- & $\begin{array}{l}\text { This research stated that, in establishing a good } \\
\text { working relationship, must be based on accurate, } \\
\text { clear perceptions, good communication, and the } \\
\text { right emotions (positive or negative). Good and } \\
\text { bad communication that occurs in schools } \\
\text { depends on the leadership of the principal. }\end{array}$ \\
\hline $\begin{array}{l}\text { Nur Agus Salim } \\
\text { (2017) }\end{array}$ & $\begin{array}{c}\text { Analisis Pengaruh } \\
\text { Manajemen Konflik Terhadap } \\
\text { Efektivitas Pengelolaan Sd Di } \\
\text { Kab. Kutai Kartanegara } \\
\text { (Analysis of the Effect of } \\
\text { Conflict Management on the } \\
\text { Effectiveness of Primary } \\
\text { School Management in Kutai } \\
\text { Kartanegara District) } \\
\end{array}$ & Indonesia & Quantitative & $\begin{array}{c}282 \\
\text { Respondents. }\end{array}$ & $\begin{array}{l}\text { Based on this research, conflicts that occur within } \\
\text { an organization certainly result in the } \\
\text { implementation of work that is ineffective and } \\
\text { inefficient. For this reason, every leader and } \\
\text { member of the organization must be able to } \\
\text { resolve or help resolve conflicts in the } \\
\text { organization with maximum conflict } \\
\text { management. }\end{array}$ \\
\hline $\begin{array}{l}\text { Michael A. } \\
\text { Hignite, Thomas } \\
\text { M. Margavio, Jerry } \\
\text { M. Chin (2020 }\end{array}$ & $\begin{array}{l}\text { Assessing the Conflict } \\
\text { Resolution Profiles of } \\
\text { Emerging Information } \\
\text { Systems Professionals }\end{array}$ & United States & Quantitative & 225 Students & $\begin{array}{l}\text { Based on this research, the conflict resolution } \\
\text { style in the conflict management series is located } \\
\text { in the lower right quadrant, which is to } \\
\text { accommodate, avoid, collaborate, and } \\
\text { compromise. While no conflict resolution style is } \\
\text { always right for all conflicts, certain styles may } \\
\text { be more appropriate for certain conflict } \\
\text { situations. }\end{array}$ \\
\hline $\begin{array}{l}\text { Jacqueline } \\
\text { Akhurst, } \\
\text { Simnikiwe } \\
\text { Magqamfana and } \\
\text { John Day (2020) }\end{array}$ & $\begin{array}{c}\text { An Action Research-Based } \\
\text { Intervention To Tackle Inter- } \\
\text { Group Conflict: A Case Study } \\
\text { Of Work With Educators In A } \\
\text { South African Secondary } \\
\text { School }\end{array}$ & Africa & Case Study & ------ & $\begin{array}{l}\text { The results of this study emphasize that it is } \\
\text { important to create an organizational atmosphere } \\
\text { that focuses on conflict management issues with } \\
\text { the main problem; personality clashes, } \\
\text { communication problems, overwork, cultural } \\
\text { differences, personal problems that affect work } \\
\text { performance, feeling misunderstood, lack of } \\
\text { respect and unresolved conflicts. }\end{array}$ \\
\hline
\end{tabular}




\begin{tabular}{|c|c|c|c|c|c|}
\hline $\begin{array}{l}\text { Ali Sabanci, Dr. } \\
\text { Ahmet Şahin, İzzet } \\
\text { Özdemir (2020) }\end{array}$ & $\begin{array}{l}\text { Interpersonal Communication } \\
\text { Skills of the Leaders of } \\
\text { Inspection Groups in Turkey }\end{array}$ & Turkey & Quantitative & 2493 Inspectors & $\begin{array}{l}\text { Effective managers and leaders must be skilled in } \\
\text { human relations, be able to develop the skills of } \\
\text { others, be able to make decisions, set an example, } \\
\text { joke, understand positive nonverbal language, } \\
\text { develop networks and encourage communication, } \\
\text { listen effectively, develop strong symbolic } \\
\text { messages, and apply power effectively. }\end{array}$ \\
\hline Syarnubi (2016) & $\begin{array}{c}\text { Manajemen Konflik Dalam } \\
\text { Pendidikan Islam Dan } \\
\text { Problematikanya: Studi Kasus } \\
\text { Di Fakultas Dakwah Uin- } \\
\text { Suka Yogyakarta } \\
\text { (Conflict Management in } \\
\text { Islamic Education and Its } \\
\text { Problems: Case Study at } \\
\text { Dakwah Faculty of UIN } \\
\text { Sunan Kalijaga Yogyakarta) }\end{array}$ & Indonesia & Qualitative & ------- & $\begin{array}{l}\text { Based on this research, conflict management } \\
\text { methods use the terms integrating, obliging, } \\
\text { dominating, avoiding and compromising. The } \\
\text { role of the leader in resolving conflicts uses the } \\
\text { method of uniting, negotiating (compromising) } \\
\text { and appealing. }\end{array}$ \\
\hline $\begin{array}{l}\text { Novianty Djafri } \\
(2020)\end{array}$ & $\begin{array}{l}\text { Efektivitas Kepemimpinan } \\
\text { Kepala Sekolah Dasar di Kota } \\
\text { Gorontalo } \\
\text { (The effectiveness of } \\
\text { Elementary School Principal } \\
\text { Leadership in Gorontalo) }\end{array}$ & Indonesia & Qualitative & 66 Principals & $\begin{array}{l}\text { Based on this research, principals in primary } \\
\text { schools in Gorontalo are always responsive in } \\
\text { resolving conflicts, either conflicts between } \\
\text { teachers, or conflicts between parents of students } \\
\text { and teachers, even between students. The } \\
\text { principal always tries to mediate between the two } \\
\text { parties without taking sides. Sometimes, conflict } \\
\text { exists because of a lack of understanding for the } \\
\text { issuing of opinions and expressions, resulting in } \\
\text { misunderstanding between the two parties. }\end{array}$ \\
\hline $\begin{array}{l}\text { Zeinab Lalegani, } \\
\text { Ali Nasr Isfahani, } \\
\text { Arash Shahin and } \\
\text { Ali Safari (2019) }\end{array}$ & $\begin{array}{l}\text { Developing a model for } \\
\text { analyzing the factors } \\
\text { influencing interpersonal } \\
\text { conflict }\end{array}$ & Iran & Mix Methods & 160 Employees & $\begin{array}{l}\text { Based on the results of this study, interpersonal } \\
\text { conflict includes individual factors (personality } \\
\text { and individual differences); Organizational } \\
\text { factors include five dimensions: organizational } \\
\text { culture, organizational structure, management } \\
\text { characteristics, intra-organizational factors and } \\
\text { human resources; and environmental factors } \\
\text { influence the creation of interpersonal conflicts. } \\
\text { Organizational factors are identified as the most } \\
\text { important factors affecting interpersonal conflict. }\end{array}$ \\
\hline $\begin{array}{c}\text { Malikeh } \\
\text { Beheshtifar, Elham } \\
\text { Zare (2013) }\end{array}$ & $\begin{array}{c}\text { Interpersonal Conflict: A } \\
\text { Substantial Factor to } \\
\text { Organizational Failure }\end{array}$ & Iran & Qualitative & ------ & $\begin{array}{l}\text { Differences in terms of goals, expectations, } \\
\text { values, proposed actions, and suggestions on how } \\
\text { to handle a situation cannot be avoided. } \\
\text { Interpersonal conflict management involves } \\
\text { changes in attitudes, behavior, and organizational } \\
\text { structure, so that members of the organization } \\
\text { can work with each other effectively to achieve } \\
\text { individual goals. }\end{array}$ \\
\hline
\end{tabular}

\section{RESULT AND DISCUSSION}

Based on the results of reviews from various sources obtained, the analysis shows that most articles focus on how a conflict arises in schools, what causes an interpersonal conflict in schools, and how the role of the principal in handling a conflict to have a positive impact on school organizations. As can be seen from the articles reviewed that conflicts that are well managed by principal will have a possitive impact on school organization.

Research on interpersonal conflict management in school has been studied in various countries. Table 1 shows that research related to this topic has been done in various educational institutions. Most of the research results show that conflict is an inseparable part of organizational life. This was explained by Adem Jemal in his research, conflict can not be avoided, but the impact can be minimized and -in many casescan be resolved. Teachers and principals must have sufficient knowledge about how to minimize conflict, and how they can respond or manage it so that it can bring positive change and minimize negative effects. (Adem, 2019). Ahmad Muslim in his research stated that the causes of interpersonal conflict in schools are these eight factors: personality, knowledge, communication, human relations, discipline, effectiveness of learning, welfare, and availability of facilities and infrastructure (Muslim, 2014). For this reason, interpersonal leadership skills are needed as a dual assessment and development process that contributes to knowledge, skills and abilities (Lu-Myers \& Myers, 2018). A school principal must be able to manage conflict. Conflict management is an effort to deal with problems or conflicts that occur both to themselves and to others (Sridasweni et al., 2017). Leaders or principals must have ideas in resolving conflicts with conflict management such as, motivating, informing, inspiring, technical competence, communicating effectively, and conveying visions of interpersonal conflict to the staffs in 
order to achieve organizational goals effectively and efficiently (Dewi, 2013). Furthermore, explained in Owan's research, Valentine Joseph that there are four main conflict management strategies, including: arbitration, dialogue (face to face), effective communication and expediting conflict management strategies (Owan, 2018). It can be concluded that conflict is an important part of management that cannot be avoided, but can be resolved and managed. However, the effect is highly dependent on how the principal in managing and deepening the understanding about interpersonal conflict so as to produce a positive impact. This must be done because the principal is the key in the decision-making process, ensuring growth, achievement of goals, and success of the school.

The general conclusion is that when conflicts are managed effectively, they can be very useful for the effectiveness of individuals and groups and will affect the sustainability of the organization.

As research in general, this review also has limitations. First, the articles reviewed were only articles written in English, so research in other languages was not reviewed due to language limitations. Second, the scope of the article reviewed is still very limited, in Indonesia, articles that fit the topic only focus on the empathy issues on the conflicting parties, as well as conflict contributions to decision-making strategies that can encourage all group members to continue to do good in achieving organizational goals.

There are many examples of leadership competencies that have been identified in the literature on how principals manage their resources. However, so far, leaders only assess the state of leadership and identify the competencies needed to succeed. (Shabbir, Atta, \& Adil, 2014).

\section{CONCLUSION}

Despite the limitations of the literature, our findings are expected to contribute information about the importance of interpersonal conflict management for principals. Conflict management is the art of managing and resolving conflicts that happen within a group or organization, including educational institutions. This research looks at from a broad context, the literature used is also from various countries in the world. Besides, this research is expected to help develop knowledge about the causes of conflict and how to effectively manage conflict, as well as strategies in interpersonal conflict management. We hope that the results of this study can be useful to help principals in dealing with conflicts that occur between individuals and groups, so that principals can provide opportunities for individuals or teams to contribute to the organization. In managing interpersonal conflict, the principal must have Ideas in resolving conflict problems, such as, motivating, informing, inspiring, technical competencies, communicating effectively, and conveying interpersonal conflict vision to subordinates, in order to achieve organizational goals effectively and efficiently. It can be concluded that conflict management has a positive and significant effect on school if managed properly by the principal.

\section{SUGGESTION}

In this study it was found that conflict management can have positive and negative impacts, and can encourage innovation, creativity, and adaptation for members of the organization. If conflicts are managed properly, and the communication is better, the conflict will have a positive impact by making changes (in a positive way) for school organizations. The principal must have many ideas in resolving conflicts with conflict management, such as, motivating, informing, inspiring, technical competence, communicating effectively, and conveying visions of interpersonal conflict to teachers and staffs in order to achieve organizational goals effectively and efficiently. Because, in implementing interpersonal conflict management, the principal must have the right approach to be able to manage conflict optimally. The actual impact of appropriate interpersonal conflict management is that it can shape a better school environment, motivate and support the achievement of the goals of school organization. This research is still very limited, it is even difficult to obtain literature that explains the effective approach strategies to be carried out by principals in managing interpersonal conflict. The next step that must be taken is that further studies (another research) must be carried out related to the strategic approach in interpersonal conflict management for the school principal.

\section{REFERENCES}

[1] Adem, J. (2019). The Practices and Challenges of Conflict Management the Case of Government Secondary Schools in Arada Sub-City. Addis Ababa University,

[2] Akhurst, J., Magqamfana, S., \& Day, J. (2020). An action research-based intervention to tackle intergroup conflict: A case study of work with educators in a South African secondary school. Community Psychology in Global Perspective, 6(1), 149-163.

[3] Baxter, J. A. (2014). An independent inspectorate? Addressing the paradoxes of educational inspection in 2013. School Leadership \& Management, 34(1), 21-38.

[4] Beenen, G., Pichler, S., \& Davoudpour, S. (2018). Interpersonal skills in MBA admissions: How are they conceptualized and assessed? Journal of Management Education, 42(1), 34-54. doi:10.1177/1052562917703743

[5] Beheshtifar, M., \& Zare, E. (2013). Interpersonal conflict: A substantial factor to organizational failure. International Journal of Academic Research in Business and Social Sciences, 3(5), 400.

[6] Bhayo, A. R., Shah, N., \& Chachar, A. A. (2017). The impact of interpersonal conflict and job stress on employees turnover intention. International Research Journal of Arts \& Humanities (IRJAH), 45(45).

[7] Chow, C. M., Ruhl, H., \& Buhrmester, D. (2013). The mediating role of interpersonal competence between adolescents' empathy and friendship quality: A dyadic approach. Journal of adolescence, $36(1)$ 191-200. doi:10.1016/j.adolescence.2012.10.004

[8] Crossfield, D., \& Bourne, P. A. (2018). Management of interpersonal conflict between principals and teachers in selected secondary schools in Bermuda. Insights of Anthropology, 2(1). doi: $10.36959 / 763 / 489$ 
[9] Dewi, R. (2013). Kinerja Kepala Sekolah: Pengaruh kepemimpinan Transformasional, konflik dan efikasi diri. Jurnal Ilmu Pendidikan, 18(2). doi:10.17977/jip.v18i2.3615

[10] Djafri, N. (2020). Efektivitas Kepemimpinan Kepala Sekolah Dasar di Kota Gorontalo. Ideas: Jurnal Pendidikan, Sosial dan Budaya, 6(1), 97-104.

[11] Emike, O. E., \& Chidi, D. M. (2020). Skill-Oriented Education And Career Competence Among Postgraduate Students In University Of Lagos, Nigeria. Ethiopian e-Journal for Research and Innovation Foresight (Ee-JRIF), 11(1).

[12] Englefield, E., Black, S. A., Copsey, J. A., \& Knight, A. T. (2019). Interpersonal competencies define effective conservation leadership. Biological Conservation, 235, 18-26. doi:10.1016/j.biocon.2019.03.043

[13] Fajrussalam, H., Badrudin, B., \& Sulhan, M. (2019). The Influence of Principal's Communication and Conflict Management towards the Work Discipline of Teachers at SMA PGRI Tanjungsiang Subang. Paper presented at the 2nd International Conference on Research of Educational Administration and Management (ICREAM 2018).

[14] Geiger, I. (2020). From Letter to Twitter: A Systematic Review of Communication Media in Negotiation. Group Decision and Negotiation, 1-44.

[15] Hariri, H., Monypenny, R., \& Prideaux, M. (2014). Leadership styles and decision-making styles in an Indonesian school context School Leadership \& Management, 34(3), 284-298. doi:10.1080/ 13632434.2013 .849678

[16] Hignite, M. A., Margavio, T. M., \& Chin, J. M. (2020). Assessing the conflict resolution profiles of emerging information systems professionals. Journal of Information Systems Education, 13(4), 6.

[17] Ihuarulam, M. O. (2015). Management strategies of conflict between academic and nonacademic staff of Federal Universities in South East, Nigeria. PGD thesis submitted to the Department of Educational Foundations (Administration and Planning), University of Nigeria, Nsukka.

[18] Lalegani, Z., Isfahani, A. N., Shahin, A., \& Safari, A. (2019). Developing a model for analyzing the factors influencing interpersonal conflict. Management Decision. doi:10.1108/MD08-2018-0857

[19] Li, D., Davis, J. E., Wang, G., Nabi, G., Bishop, V. R., Sun, Y., . . Lei, F. (2020). Coping with extremes: Remarkably blunt adrenocortical responses to acute stress in two sympatric snow finches on the Qinghai-Tibet Plateau during winter relative to other seasons. General and Comparative Endocrinology, 291, 113434.

[20] Lu-Myers, Y., \& Myers, C. G. (2018). Incorporating interpersonal skills into otolaryngology resident selection and training. Otolaryngology-Head and Neck Surgery, 158(1), 21-23.

[21] Muslim, A. (2014). Manajemen Konflik Interpersonal di Sekolah. Jurnal Paedagogy, 1(2), 123-133.

[22] Owan, V. J. (2018). Conflict management strategies and secondary school teachers' job effectiveness in Obubra Local Government Area of Cross River State, Nigeria. Owan, VJ (2018). Conflict management strategies and secondary school teachers' job effectiveness in Obubra Local Government Area of Cross River State, Nigeria. B. Ed. Project, University of Calabar.

[23] Putra, A. E., \& Nugroho, A. S. (2019). Manajemen Perpustakaan Dalam Meningkatkan Minat Baca Peserta Didik. Ta'lim.

[24] Sabanci, A., Sahin, A., \& Özdemir, İ. (2016). Interpersonal Communication Skills of the Leaders of Inspection Groups in Turkey. Online Submission, 5(4), 148-159.

[25] Salim, N. A., Haruna, J., \& Saraka, S. (2017). Analisis Pengaruh Manajemen Konflik Terhadap Efektivitas Pengelolaan SD DI KAB. Kutai Kartanegara. PENDAS MAHAKAM: Jurnal Pendidikan Dasar, 2(3), 250-260.

[26] Shabbir, N., Atta, M., \& Adil, A. J. J. o. B. S. (2014). Conflict management and decision making styles in college management. 24(2), 52 .

[27] Siswidiyanto, S., \& Puspasari, A. (2018). Pengaruh Komunikasi Dan Kepemimpinan Dalam Penyelesaian Konflik. Jurnal Ilmiah
MEA (Manajemen, Ekonomi, \& Akuntansi), 2(3), 28-36. doi:10.31955/mea.vol2.iss3.pp28-36

[28] Sridasweni, S., Yusuf, A. M., \& Sabandi, A. (2017). Hubungan Kecerdasan Emosional dan Komunikasi Interpersonal Dengan Manajemen Konflik Peserta Didik. INSIGHT: Jurnal Bimbingan Konseling, 6(2), 176-193.

[29] Syarnubi, S. (2016). Manajemen Konflik Dalam Pendidikan Islam dan Problematikanya: Studi Kasus di Fakultas Dakwah UINSUKA Yogyakarta. Tadrib: Jurnal Pendidikan Agama Islam, 2(1), 151-178.

[30] Taayina, S. (2019). Mechanisms For Preventing, Managing And Resolving Inter-Religious Conflicts In Some Selected Senior High Schools In The Upper West Region.

[31] Wulandari, K. P. (2019). Interpersonal Communication Approach to School Head of Teacher Development. Paper presented at the the 4th International Conference on Education and Management (COEMA 2019).

[32] Zuelke, A. E., Roehr, S., Schroeter, M. L., Witte, A. V., Hinz, A., Engel, C., . . . Villringer, A. (2020). Are social conflicts at work associated with depressive symptomatology? Results from the population-based LIFE-Adult-Study. Journal of occupational medicine and toxicology, 15(1), 1 . 